\title{
PENGARUH SISTEM INFORMASI AKUNTANSI (KOMPUTERISASI KEGIATAN PERTANAHAN) TERHADAP PENCATATAN PENERIMAAN NEGARA BUKAN PAJAK PADA KANTOR PERTANAHAN KABUPATEN BENGKALIS
}

\author{
Dewi Angraini, Decky Hendarsyah \\ Sekolah Tinggi Ilmu Ekonomi (STIE) Syariah Bengkalis \\ Email: dewiangraini2708@gmail.com, deckydb@gmail.com
}

\begin{abstract}
ABSTRAK
Penelitian ini dilakukan untuk mengetahui pengaruh Sistem Informasi Akuntansi (Komputerisasi Kegiatan Pertanahan) terhadap Pencatatan PNBP menurut PP No. 128 Tahun 2015. Penelitian ini dilakukan pada Kantor Pertanahan Kabupaten Bengkalis. Pengumpulan data dilakukan dengan memberikan kuesioner sebanyak 30 eksemplar, yang dibagikan kepada responden yang merupakan Pegawai Negeri Sipil dan Pegawai tidak tetap pada Kantor Pertanahan Kabupaten Bengkalis dengan menggunakan Purposive Sampling. Data yang diperoleh kemudian dianalisis menggunakan SPSS versi 23.0. Hasil pengujian menunjukkan bahwa Sistem Informasi Akuntansi (komputerisasi kegiatan pertanahan) berpengaruh positif dan signifikan terhadap pencatatan Penerimaan Negara Bukan Pajak pada Kantor Pertanahan Kabupaten Bengkalis. Sumbangan pengaruh variabel independen terhadap variabel dependen adalah sebesar $25,3 \%$ sedangkan sisanya $74,7 \%$ dipengaruhi oleh variabel lain.
\end{abstract}

Kata kunci: Sistem Informasi Akuntansi, Pajak, Pertanahan.

\begin{abstract}
This study was conducted to determine the effect of Accounting Information Systems (Computerization of Land Activities) on the Registration of Records of Non-Tax State Revenues according to Government Regulation Number 128 of 2015. This research was conducted at the Land Office of Bengkalis Regency. Data collection was done by giving questionnaires as much as 30 copies, which were distributed to respondents who are civil servants and non-permanent employees at the Bengkalis land office using Purposive Sampling. The data obtained were then analyzed using SPSS version 23.0. The test results show that the Accounting Information System (computerization of land activities) has a positive and significant effect on the recording of non-tax state revenue at the Bengkalis Regency land office. The contribution of the independent variable to the dependent variable is $25.3 \%$ while the rest $74.7 \%$ is influenced by other variables.
\end{abstract}

Keyword: Accounting information system, Tax, Land.

\section{PENDAHULUAN}

Pada saat ini kemajuan suatu Negara sudah tidak bisa terlepas dari kemajuan teknologi yang digunakan, sama halnya dengan Indonesia yang merupakan 
Negara berkembang yang pertumbuhan ekonominya tidak bisa terlepas dari kemajuan teknologi yang digunakan.

Pertumbuhan ekonomi suatu Negara ditunjang dari pendapatan yang diterimanya guna melaksanakan kegiatan atau program kerja pemerintahan untuk kemajuan perekonomian dan kemakmuran rakyat seperti belanja negara, perbaikan sarana dan prasarana, pembangunan infrastruktur dan lain sebagainya. Pendapatan suatu Negara merupakan aspek penting guna kestabilan kinerja pemerintahan.

Penerimaan Negara bukan pajak merupakan salah satu dari bentuk penerimaan Negara yang diterima bukan melalui sektor perpajakan. Jadi segala bentuk penerimaan Negara yang didapat tidak melalui atau tidak berkaitan dengan perpajakan maka itulah yang disebut dengan penerimaan bukan pajak atau yang sering disebut dengan istilah non tax.

Menurut Undang-undang Republik Indonesia Nomor 20 Tahun 1997 dalam Bab I Pasal 1 Ayat 1 Penerimaan Negara Bukan Pajak adalah seluruh penerimaan Pemerintah Pusat yang tidak berasal dari penerimaan perpajakan. Penerimaan Negara Bukan Pajak atau yang disingkat dengan PNBP telah diatur oleh pemerintah dalam Undang-undang Republik Indonesia sebagai dasar hukumnya baik dari segi penjelasannya, jenis dan penyetorannya, penggunaannya dan tata cara penyampaian rencana dan laporan realisasinya. Tujuannya adalah agar PNBP dapat di kelola dengan baik, baik dari segi penerimaanya maupun penggunaannya, sehingga PNBP dapat dipertanggung jawabkan dengan baik oleh pihak yang berwenang demi menghindari kecurangan. Sesuai dengan Undang-undang RI No 20 Tahun 1997 pada Bab III Pasal 4 dijelaskan bahwa seluruh Penerimaan Negara Bukan Pajak wajib disetor langsung secepatnya ke Kas Negara.

Kantor Pertanahan Kabupaten Bengkalis merupakan instansi vertikal di bawah pemerintahan pusat yaitu Kementerian Agraria dan Tata Ruang/Badan Pertanahan Nasional. Kementerian Agraria dan Tata Ruang/Badan Pertanahan Nasional atau di singkat dengan Kementerian ATR/BPN merupakan lembaga pemerintahan yang melaksanakan tugas pemerintahan dibidang pertanahan. Didalam menjalankan tugasnya melayani masyarakat Kementerian Agraria dan Tata Ruang/BPN melakukan pemungutan dalam bentuk PNBP yang jenis dan jumlahnya telah diatur dalam PP No.128 Tahun 2015.

Sesuai dengan surat edaran dari Kementerian Agraria dan Tata Ruang/Badan Pertanahan Nasional tanggal 22 juni 2016 No.2874/2.2-100/VI/2016 Perihal Revisi Buku pedoman dan Pertanggungjawaban bendahara pada poin No. 1.d bahwa Penyetoran PNBP yang dilaksanakan oleh wajib setor/pemohon langsung ke Kas Negara dibukukan di Buku Pencatatan dan Penyetoran PNBP secara inout. Pencatatan hendaklah dilakukan secara benar dan tepat sehingga bisa dipertanggungjawabkan pada saat membuat Laporan Rekapitulasi PNBP fungsional yang dilakukan pada setiap akhir bulan.

Pencatatan yang dilakukan secara manual sangat rentan dengan kesalahan, kecurangan dan manipulasi. Namun seiring dengan berkembangnya zaman dan teknologi maka dibutuhkan sebuah sistem yang mampu membantu mengolah data dan informasi yang tepat dan akurat guna memudahkan dalam pencatatan PNBP sehingga kesalahan dan kecurangan bisa di kurangi, sistem tersebut dinamakan Sistem Informasi Akuntansi. Sistem Informasi Akuntansi atau yang disingkat dengan SIA adalah sebuah sistem yang memproses data dan transaksi guna 
menghasilkan informasi yang bermanfaat untuk merencanakan, mengendalikan, dan mengoperasikan bisnis (Krismiaji, 2010, 4).

Berdasarkan penelitian terdahulu yang dilakukan oleh (Silviana, 2014, 34) yang berjudul Pengaruh Sistem Informasi Akuntansi terhadap Kualitas Laporan Keuangan Pemerintah Daerah Survey pada Pemerintah Kabupaten di seluruh Jawa Barat menyatakan bahwa, dari hasil analisis pengujian dapat disimpulkan bahwa Penerapan SIA berpengaruh terhadap kualitas LKPD.

LKPD merupakan salah satu bentuk laporan keuangan yang menggambarkan posisi keuangan suatu daerah, salah satu yang di gambarkan dalam LKPD adalah pendapatan yang diterima oleh daerah, dan pendapatan yang diterima telah tercatat sebelumnya secara tepat dan akurat oleh pihak-pihak yang berwenang sehingga laporan yang di hasilkan berkualitas, sesuai dengan keadaan sebenarnya. Begitu juga dengan Kantor Pertanahan Kabupaten Bengkalis yang melakukan pencatatan terhadap PNBP yang telah disetorkan oleh wajib setor sehingga mampu melaporkannya dalam bentuk Laporan Rekapitulasi PNBP pada setiap bulannya.

Sesuai dengan surat edaran dari Kementerian Agraria dan Tata Ruang/Badan Pertanahan Nasional tanggal 22 juni 2016 No.2874/2.2-100/VI/2016 Perihal Revisi Buku pedoman dan Pertanggungjawaban bendahara Pada poin No.1 dijelaskan bahwa petugas penerimaan setoran PNBP setiap bulan sekali membuat Laporan Rekapitulasi PNBP Fungsional dan mengirimkannya kepada Bendahara Penerima Kementerian Agraria dan Tata Ruang/Badan Pertanahan Nasional.

Laporan Rekapitulasi PNBP Fungsional yang sampaikan hendaklah tepat dan akurat atau sesuai dengan faktanya, tidak ada unsur rekayasa. Hal tersebut tentu saja berkaitan erat dengan sistem yang digunakan pada pencatatan penerimaan PNBP tersebut, karena laporan rekapitulasi PNBP Fungsional di dapat dari hasil pencatatan PNBP pada setiap harinya dalam satu bulan yang dilakukan oleh petugas penerima setoran PNBP, tidak boleh ada kesalahan, kelalaian bahkan kecurangan dalam melakukan pencatatan. Pencatatan PNBP harus dilakukan secara teliti dan seksama sehingga bisa menghasilkan laporan rekapitulasi PNBP yang tepat dan akurat.

Kementerian Agraria dan Tata Ruang/Badan Pertanahan Nasional sudah menerapkan SIA dalam bentuk sistem yang disebut KKP atau Komputerisasi Kegiatan Pertanahan sejak tahun 2010 pada seluruh proses permohonan berkas pada loket pelayanan pendaftaran berkas, tak terkecuali Kantor Pertanahan Kabupaten Bengkalis.

Penerapan sistem ini sangat membantu loket pelayanan dalam menjalankan tugas dan fungsinya dalam melayani masyarakat, salah satunya adalah memudahkan petugas loket dalam menghitung tarif PNBP sesuai jenis yang telah diatur dalam PP No.13 Tahun 2015. Namun setelah hampir tujuh diterapkan KKP, petugas penerima setoran PNBP masih tetap melakukan pencatatan secara manual entry sesuai surat edaran Kementerian Agraria dan Tata Ruang/Badan Pertanahan Nasional tanggal 22 juni 2016 No.2874/2.2-100/VI/2016 Perihal Revisi Buku pedoman dan Pertanggungjawaban bendahara.

Hampir pada setiap harinya petugas penerima setoran PNBP melakukan kesalahan didalam melakukan pencatatan seperti kekurangan pencatatan bukti setor atau kelebihan pencatatan angka bukti setor, hal ini dikarenakan Program Excel memiliki banyak kelemahan seperti masih manual entry, peluang terjadinya 
kesalahan dalam pengetikan dan data bisa terhapus sangat besar dan masih banyak lagi. Sehingga bisa disimpulkan bahwa pencatatan menggunakan program excel keakuratan datanya masih diragukan.

Sistem Informasi Akuntansi (Komputerisasi Kegiatan Pertanahan) yang diterapkan di kantor pertanahan Kabupaten Bengkalis juga masih sering mengalami kendala seperti gangguan jaringan pada aplikasinya sehingga pengentrian data terhambat dan pelayanan pun menjadi lambat. Gangguan jaringan yang terjadi pada Komputerisasi Kegiatan Pertanahan juga menjadikan pencatatan transaksi kedalam sistem menjadi tenganggu seperti tanggal dan waktu bukti setoran dari Bank bisa berbeda yang tercatat di Komputerisasi Kegiatan Pertanahan.

Adapun tujuan dari penelitian ini adalah sebagai berikut:

1. Untuk mengetahui bagaimana Sistem Informasi Akuntansi (Komputerisasi Kegiatan Pertanahan) dan Pencatatan Penerimaan Negara Bukan Pajak (PNBP) pada Kantor Pertanahan Kabupaten Bengkalis.

2. Untuk Mengetahui apakah Sistem Informasi Akuntansi (Komputerisasi Kegiatan Pertanahan) berpengaruh pada pencatatan penerimaan Negara Bukan Pajak pada Kantor Pertanahan Kabupaten Bengkalis.

3. Untuk mengetahui bagaimana pandangan Islam terhadap Sistem Informasi Akuntasi (Komputerisasi Kegiatan Pertanahan) dan pencatatan Penerimaan Negara Bukan Pajak (PNBP).

\section{TINJAUAN PUSTAKA}

\section{Sistem Informasi Akuntasi}

Sistem Informasi Akuntansi (SIA) merupakan gabungan dari tiga kata, yaitu sistem, informasi, dan akuntansi (Efendi et. al. 2013, 73). Sistem adalah serangkaian dua komponen atau lebih yang saling berkaitan dan berinteraksi untuk mencapai tujuan. Sebuah sistem dapat terdiri dari beberapa bagian atau yang disebut dengan istilah Subsistem, misalnya saja sistem Komputer yang terdiri dari subsistem perangkat lunak dan subsistem perangkat keras, dan subsistem pun terdiri dari subsistem-subsistem atau yang disebut dengan komponen-komponen pendukung dari sistem itu sendiri seperti perangkat keras terdiri dari beberapa komponen seperti alat masukan, alat keluaran, alat pemeroses dan media penyimpanan. Setiap subsistem akan saling bekerjasama dan berinteraksi untuk mecapai tujuan atau sasaran dari sistem tersebut (Romney 2016, 3).

Informasi adalah data yang telah diolah atau dianalisis dengan suatu cara bermakna sehingga dapat memberikan manfaat (arti) bagi pengguna. Manfaat dari informasi adalah bagi penggunanya bisa dijadikan acuan dalam membuat keputusan untuk langkah kedepan yang akan ditempuh oleh penggunanya (Helmawati 2015, 17).

Akuntansi adalah sistem informasi yang mengukur akitivitas bisnis, mengolah data jadi laporan, dan mengkomunikasikan hasilnya kepada para pengambil keputusan (Jusup 2011, 4). Selain itu juga makna lain dari akuntansi adalah suatu sistem informasi yang mengidentifikasi, mencatat, dan mengkomunikasikan kejadian ekonomi dari suatu organisasi kepada pihak yang berkepentingan (Yadiati 2008, 6). Dari pengertiannya jelas bahwa akuntansi adalah sistem yang 
digunakan untuk mengukur seluruh aktivitas ekonomi yang terjadi dalam sebuah usaha, lalu data yang telah didapat diolah dalam bentuk laporan dan hasilnya dapat digunakan bagi pihak yang berkepentingan untuk mengambil keputusan. Tujuan akuntansi secara keseluruhan adalah memberikan informasi yang dapat digunakan dalam pengambilan keputusan (Hery 2011). Peranan dari akuntansi adalah untuk memberikan informasi mengenai perilaku ekonomi yang diakibatkan oleh aktivitas-aktivitas perusahaan dalam lingkungannya (Riahi 2006, 54).

Sistem Informasi Akuntansi adalah sebuah sistem yang memproses data dan transaksi guna menghasilkan informasi yang bermanfaat untuk merencanakan, mengendalikan, dan mengoperasikan bisnis (Krismiaji 2010, 4). Menurut Moscove Sistem Informasi Akuntansi adalah suatu komponen organisasi yang mengumpulkan, mengklasifikasikan, mengolah, menganalisa dan mengkomunikasikan informasi finansial dan pengambilan keputusan yang relevan kepada pihak di luar perusahaan (seperti Kantor pajak, investor, dan kreditor) dan pihak intern (terutama manajemen) (Baridwan 2011, 3).

Dalam menjalankan peranannya, SIA memiliki tujuan adalah (Efendi 2013, 74):

1. Menyediakan informasi bagi pengelola kegiatan usaha baru.

2. Memperbaiki informasi yang dihasilkan oleh sistem yang sudah ada.

3. Memperbaiki pengendalian akuntansi dan pengecekan intern, yaitu untuk memperbaiki tingkat keandalan (reability) informasi akuntansi dan penyediaan catatan lengkap mengenai pertanggungjawaban dan perlindungan kekayaan perusahaan

4. Mengurangi biaya klerikal dalam penyelengaraan catatan akuntansi.

Sistem informasi akuntansi harus melaksanakan tugas-tugas sebagai berikut (Krismiaji, 2010, 4-5):

1. Mengumpulkan transaksi dan data lain dan memasukkan kedalam sistem.

2. Memproses data transaksi.

3. Menyimpan data untuk keperluan di masa mendatang.

4. Menghasilkan informasi yang diperlukan dengan memproduksi laporan, atau memungkinkan para pemakai untuk melihat sendiri data yang tersimpan dikomputer.

5. Mengendalikan seluruh proses sedemikian rupa sehingga informasi yang dihasilkan akurat dan dapat dipercaya.

Adapun penggunaan Informasi Akuntansi sebagai berikut (Rama 2008, 19):

1. Menyusun Laporan eksternal.

2. Menangani transaksi-transaksi rutin.

3. Membantu para manajer membuat keputusan-keputusan rutin.

4. Membantu perencanaan dan pengendalian.

5. Memelihara pengendalian internal.

Informasi adalah data yang telah dikelola dan di proses untuk memberikan arti dan memperbaiki proses pengambilan keputusan (Rama 2008, 4). Informasi yang diperoleh bersumber dari data, data dapat diartikan sebagai kumpulan karakter, fakta atau jumlah-jumlah yang merupakan masukan (input) bagi suatu sistem informasi (Baridwan 2011, 4). Data saja belum bisa dijadikan sebagai acuan dalam pengambilan keputusan, namun informasilah yang bisa digunakan ssebagai acuan, hal ini dikarenakan informasi merupakan output atau hasil dari pengolahan data. SIA melaksanakan empat tugas dasar pengolahan data: pengumpulan data, 
manipulasi data, penyimpanan data, dan penyiapan dokumen (Mc.Leod 2004, 237).

Sistem Informasi dapat menjadi sistem manual dengan pensil dan kertas, sistem kompleks yang menggunakan TI terbaru, atau sesuatu diantara keduanya. Terlepas dari pendekatan yang diambil, prosesnya adalah sama (Romney 2006, 11).

Ada lima komponen dari SIA, yaitu (Romney 2006, 3):

1. Orang yang menggunakan sistem.

2. Prosedur dan instruksi yang digunakan untuk mengumpulkan, memproses, dan menyimpan data.

3. Data mengenai organisasi dan aktivitas lainnya.

4. Perangkat lunak yang digunakan untuk mengolah data.

5. Infrastruktur teknologi informasi meliputi komputer, perangkat peripheral, dan perangkat jaringan komunikasi yang digunakan didalam SIA.

SIA yang didesain dengan baik, dapat menambah nilai untuk organisasi dengan (Romney 2006, 11-12):

1. Meningkatkan kualitas dan mengurangi biaya produk atau jasa. Contohnya, SIA dapat memonitor mesin sehingga operator akan diberitahukan sesegera mungkin ketika kinerja berada diluar batas kualitas yang akan dapat diterima. Ini membantu menjaga kualitas produk, mengurangi limbah, dan mengurangi biaya.

2. Meningkatkan efisiensi. Contohya, informasi yang tepat waktu membuat pendekatan manufaktur just-in-time menjadi memungkinkan, karena pendekatan itu membutuhkan informasi yang konstan, akurat, dan terbaru mengenai persediaan bahan baku dan lokasi mereka.

3. Berbagi pengetahuan. Berbagi pengetahuan dan keahlian dapat meningkatkan operasi dan keunggulan komptetitif. Contohnya, Kantor akuntan publik menggunakan sistem informasi mereka untuk berbagi praktik terbaik dan untuk mendukung komunikasi antarkantor. Karyawan dapat mencari database perusahaan untuk mengidentifikasi ahli untuk memberikan bantuan untuk klien tertentu; dengan demikian, keahlian internasional Kantor akuntan publik dapat tersedia untuk klien lokal.

4. Meningkatkan efisiensi dan efektivitas rantai pasokannya. Contohnya, memungkinkan pelanggan untuk secara langsung mengakses persediaan dan sistem entri pesanan penjualan yang dapat mengurangi penjualan dan biaya pemasaran, sehingga meningkatkan tingkat retensi pelanggan.

5. Meningkatkan struktur pengendalian internal. SIA dengan struktur pengendalian internal yang tepat dapat membantu melindungi sistem dari kecurangan, kesalahan, kegagalan sistem, dan bencana.

6. Meningkatkan pengambilan keputusan.

Terdapat berbagai faktor yang mempengaruhi didalam menyusun SIA, namun faktor ini bukan berasal dari sistem akuntansi, namun faktor tersebut mempengaruhi keberhasilan dari suatu sistem, faktor-faktor itu antara lain perilaku manusia didalam organisasi, penggunaan metode kuantitatif, dan juga penggunaan Komputer sebagai alat bantu (Baridwan 2011, 7). Sistem Informasi Akuntansi Terkomputerisasi adalah sistem informasi dimana semua proses transaksi dilakukan atau berbantu secara komputer dan terpusat, baik melakukan input, proses, dan output data (Aviana 2012, 66). 


\section{Pencatatan Penerimaan Negara Bukan Pajak (PNBP)}

Peraturan Pemerintah Nomor 71 Tahun 2010 pasal 1 ayat (8) menyatakan bahwa standar akuntansi pemerintahan bebasis akrual adalah standar akuntansi pemerintahan yang mengakui adanya pendapatan, beban, aset, utang, dan ekuitas dalam pelaporan finansial berbasis akrual, serta mengakui pendapatan, belanja, dan pembiayaan dalam pelaporan pelaksanaan anggaran berdasarkan basis yang ditetapkan dalam APBN/APBD (Lamonisi 2016, 225). Berdasarkan akuntansi akrual (accrual accouting), pendapatan diakui saat dihasilkan dan beban saat terjadi, tanpa memperhatikan penerimaan atau pembayaran kas (Subramanyam 2010, 90).

Pencatatan adalah kegiatan atau proses pengdokumentasian suatu aktifitas dalam bentuk tulisan. Pencatatan dilakukan di atas kertas, disket, pita nam, pita film. Bentuk catatan dapat berupa tulisan, grafik, gambar dan suara. Selanjutnya untuk melengkapi pencatatan setiap kegiatan yang dilakukan diakhiri dengan pembuatan laporan (Massweeto 2018). Pencatatan merupakan bagian seni dari akuntansi, akuntansi adalah seni pencatatan, penggolongan, dan peringkasan transaksi yang bersifat keuangan dengan cara yang berdaya guna dan dalam bentuk satuan uang (Suwadjono 2009, 5).

Penerimaan Negara Bukan Pajak Menurut Undang-undang Republik Indonesia Nomor 20 Tahun 1997 dalam BAB I pasal 1 ayat 1 Penerimaan Negara Bukan Pajak adalah seluruh penerimaan Pemerintah Pusat yang tidak berasal dari penerimaan perpajakan. Menurut Undang-undang Republik Indonesia Nomor 20 Tahun 1997 dalam BAB I pasal 2 ayat 1 kelompok Penerimaan Negara Bukan Pajak meliputi: ${ }^{1}$

a. Penerimaan yang bersumber dari pengolahan dana pemerintahan;

b. Penerimaan dari pemanfaatan sumber daya alam,;

c. Penerimaan dari hasil-hasil pengolahan kekayaan Negara yang dipisahkan;

d. Penerimaan dari kegiatan pelayanan yang dilaksanakan Pemerintah;

e. Penerimaan berdasarkan putusan pengadilan dan berasal dari pengenaan pengenaan denda adminitrasi;

f. Penerimaan berupa hibah yang merupakan hak Pemerintah;

g. Penerimaan lainya yang diatur dalam Undang-undang tersendiri.

PNBP menurut PP No. 128 Tahun 2015 telah mengatur jenis dan tarif PNBP yang berlaku pada Kementerian Agraria dan Tata Ruang/Badan Pertanahan Nasional. $^{2}$

\section{Landasan Hukum Islam}

Landasan hukum Islam tentang Sistem Informasi Akuntansi (Komputerisasi Kegiatan Pertanahan) dan Pencatatan Penerimaan Negara Bukan Pajak (PNBP) adalah Al-Quran surat Al-Baqarah ayat 282 (Depag RI 2005):

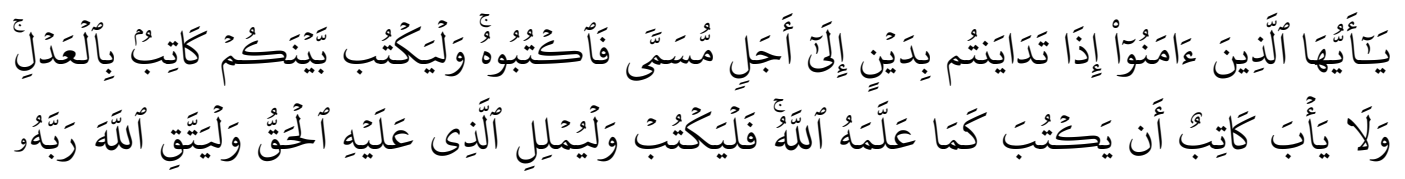

\footnotetext{
${ }^{1}$ Undang-undang Republik Indonesia Nomor 20 Tahun 1997.

2 PP No.13 Tahun 2015 Tentang Jenis dan Tarif PNBP di Kementrian Agraria dan Tata Ruang/Badan Pertanahan Nasional
} 


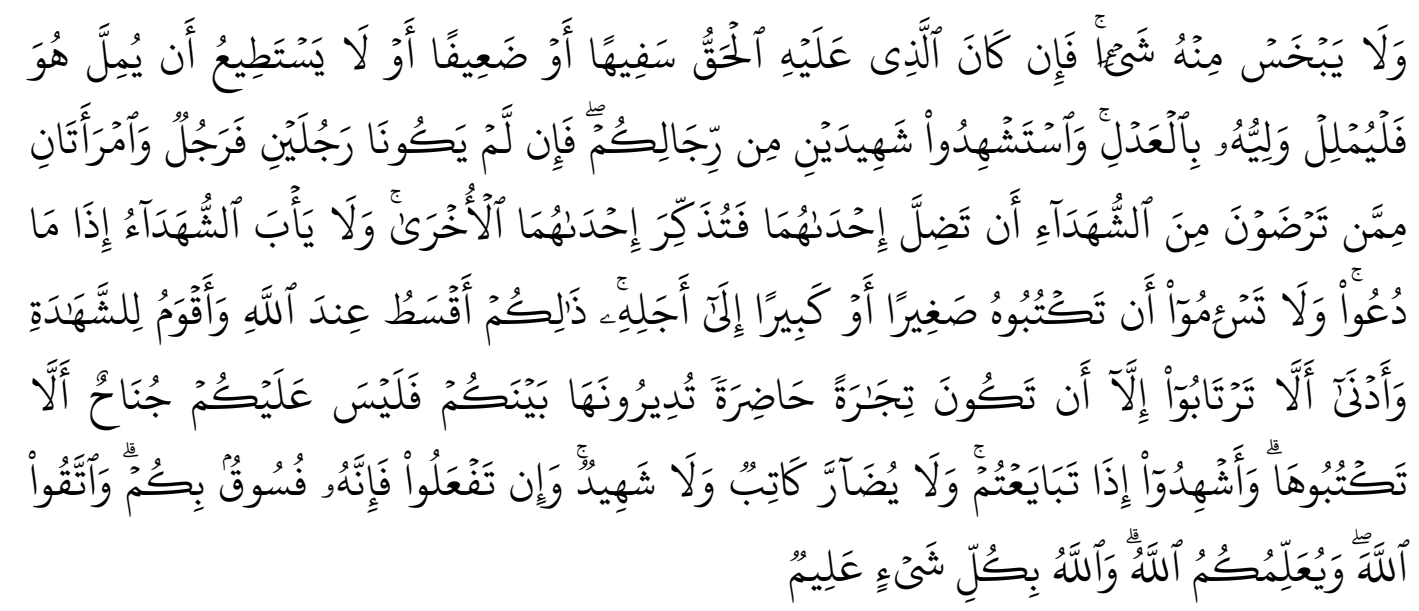

Artinya: Hai orang-orang yang beriman, apabila kamu melakukan utang piutang untuk waktu yang ditentukan, hendaklah kamu menuliskannya. dan hendaklah seorang penulis di antara kamu menuliskannya dengan benar. dan janganlah penulis enggan menuliskannya sebagaimana Allah mengajarkannya, meka hendaklah ia menulis, dan hendaklah orang yang berhutang itu mengimlakkan (apa yang akan ditulis itu), dan hendaklah ia bertakwa kepada Allah Tuhannya, dan janganlah ia mengurangi sedikitpun daripada hutangnya. jika yang berhutang itu orang yang lemah akalnya atau lemah (keadaannya) atau Dia sendiri tidak mampu mengimlakkan, Maka hendaklah walinya mengimlakkan dengan jujur. dan persaksikanlah dengan dua orang saksi dari orang-orang lelaki (di antaramu). jika tak ada dua orang lelaki, Maka (boleh) seorang lelaki dan dua orang perempuan dari saksi-saksi yang kamu ridhai, supaya jika seorang lupa Maka yang seorang mengingatkannya. janganlah saksi-saksi itu enggan (memberi keterangan) apabila mereka dipanggil; dan janganlah kamu jemu menulis hutang itu, baik kecil maupun besar sampai batas waktu membayarnya. yang demikian itu, lebih adil di sisi Allah dan lebih menguatkan persaksian dan lebih dekat kepada tidak (menimbulkan) keraguanmu. (Tulislah mu'amalahmu itu), kecuali jika mu'amalah itu perdagangan tunai yang kamu jalankan di antara kamu, Maka tidak ada dosa bagi kamu, (jika) kamu tidak menulisnya. dan persaksikanlah apabila kamu berjual beli; dan janganlah penulis dan saksi saling sulit menyulitkan. jika kamu lakukan (yang demikian), Maka Sesungguhnya hal itu adalah suatu kefasikan pada dirimu. dan bertakwalah kepada Allah; Allah mengajarmu; dan Allah Maha mengetahui segala sesuatu.

Ayat diatas merupakan ayat akuntansi, semua pesan akuntansi termakna didalam ayat tersebut. Ayat tersebut Merupakan ayat terpanjang dalam Al Quran dan secara jelas berisi perintah praktek pencatatan dalam transaksi ekonomi. Ayat ini merupakan ayat yang paling terang-terangan membahas praktek akuntansi, terdapat 8 kata yang berakar dari kata mencatat (,tubesret taya malad (ب ك sedang mencatat merupakan bagian dari fungsi utama akuntansi (Gustani, 2017). Perintah tulis menulis mencakup perintah kepada kedua orang yang bertransaksi, dalam arti salah seorang menulis dan apa yang dituliskan di serahkan kepada mitranya jika mitra pandai tulis baca, dan bila tidak pandai, atau keduanya tidak pandai maka hendaklah mencari orang ketiga(Daud 2016).

Ayat tersebut menunjukkan kewajiban bagi umat beriman untuk menulis setiap transaksi yang dilakukan dan masih belum tuntas. Tujuan perintah surat tersebut adalah untuk menjaga keadilan dan kebenaran, artinya perintah tersebut 
ditekankan pada kepentingan pertanggungjawaban agar pihak-pihak yang terlibat dalam transaksi tidak dirugikan, sehingga tidak menimbulkan konflik, dan untuk menciptakan transaksi yang adil maka diperlukan saksi. (Adnan 2005)

Dari ayat ini juga dapat dicatat bahwa dalam islam sejak munculnya peradaban Islam sejak Nabi Muhammad saw telah ada perintah untuk melakukan sistem pencatatan yang tekanannya adalah untuk tujuan kebenaran, kepastian, keterbukaan, keadilan antara dua pihak yang mempunyai hubungan muamalah (Harahap 2001, 120).

Tekanan Islam dalam kewajiban pencatatan adalah (Harahap, 2001, 121):

1. Menjadi bukti dilakukannya transaksi (muamalah) yang menjadi dasar nantinya dalam menyelesaikan persoalan selanjutnya.

2. Menjadi agar tidak terjadi manipulasi, atau penipuan baik dalam transaksi maupun hasil dari transaksi itu (laba). Dalam akuntansi tujuan pencatatan adalah:
a. Pertanggungjawaban (accountability) atau sebagai bukti transaksi
b. Penentuan pendapatan (income determination)
c. Informasi yang digunakan dalam proses pengambilan keputusan
d. Sebagai alat persaksian yang akan dipergunakan dikemudian hari, dan lain-lain.

\section{METODE PENELITIAN}

Subjek dari penelitian ini adalah Kantor Pertanahan Kabupaten Bengkalis dan objek dari penelitian ini adalah Sistem Informasi Akuntansi (Komputerisasi Kegiatan Pertanahan) dan Pencatatan Penerimaan Negara Bukan Pajak (PNBP). Populasi pada penelitian ini adalah seluruh Pegawai Negeri Sipil yang berjumlah 37 orang. Teknik pengambilan sampel yang digunakan adalah Purposive Sampling. Sehingga sampel didapat berjumlah 30 orang yang merupakan orangorang yang berkaitan dengan Sistem Informasi Akuntansi (Komputerisasi Kegiatan Pertanahan) dan Pencatatan Penerimaan Negara Bukan Pajak (PNBP). Penelitian ini mengunakan jenis pendekatan kuantitatif dan dibantu dengan software SPSS Versi 23.0. Sedangkan teknik pengumpulan data yang dilakukan adalah: observasi, wawancara, kuesioner, dokumentasi dan studi pustaka.

\section{Uji Validitas Data}

Uji validitas data digunakan untuk memberikan nilai terhadap hasil jawaban dari instrumen yang telah diberikan kepada responden, setiap skor yang diberikan oleh responden pada setiap pertanyaan akan dikorelasikan dengan skor total. Skor total adalah adalah jumlah dari semua skor pertanyaan atau pernyataan. Jika skor tiap butir pertanyaan berkorelasi secara signifikan dengan skor total dengan tingkat alfa tertentu (misalnya 1\%) maka dapat dikatakan bahwa alat pengukur itu valid. Sebaliknya jika korelasinya tidak signifikan, alat pengukur itu tidak valid dan alat ukur tersebut tidak perlu dipakai lagi untuk mengukur atau mengambil data. (Sanusi 2013, 77)

Pengujian ini dilakukan untuk memenentukan seberapa erat hubungan antara satu variabel dengan variabel lainya. Ukuran yang menyatakan keeratan hubungan tersebut adalah koefisien korelasi atau sering disebut dengan korelasi Pearson (pearson product moment) (Sanusi 2013, 122). Pada penelitian nilai r hitung akan 
dibandingkan dengan $r$ tabel dengan tingkat alfa 5\% dengan derajat bebas ( $n-2)$. Jika nilai $r$ hasil perhitungan lebih besar dari $r$ dalam tabel pada alfa tertentu maka berarti signifikan sehingga disimpulkan bahwa butir pertanyaan atau pernyataan itu valid (Sanusi 2013, 77).

\section{Uji Reliabilitas Data}

Untuk uji reliabilitas dalam penelitian ini digunakan koefisien Alpha cronbach's. koefisien ini merupakan reliabilitas yang paling sering digunakan karena koefisien ini menggambarkan variasi dari item-item, baik untuk format benar atau salah atau bukan, seperti format pada skala likert sehingga koefisien yang paling umum digunakan untuk mengevaluasi internal consistency. Uji ini digunakan agar penelitian tersebut dapat diandalkan dan dipercaya atau disebut reliabel Jika koefisien alpha yang dihasilkan lebih besar dari $0.60(a>0,60)$ maka instrumen tersebut dikatakan reliabel, apabila sebaliknya alpha lebih rendah dari $0,60(a<0,60)$ maka instrumen tersebut tidak reliabel.

\section{Uji Korelasi}

Koefisien korelasi adalah bilangan yang menyatakan kekuatan hubungan antara dua variabel atau lebih atau juga dapat menentukan arah dari kedua variabel. Nilai korelasi $(r)=(-1 \leq 0 \leq 1)$. Untuk kekuatan hubungan, nilai koefisien korelasi berada di antara -1 dan 1 , sedangkan untuk arah dinyatakan dalam bentuk positif (+) dan negatif (-). (Sanusi 2013, 251)

Tabel 1

Tingkat Korelasi dan Kekuatan Hubungan

\begin{tabular}{|c|l|l|}
\hline No & \multicolumn{1}{|c|}{ Nilai Korelasi (r) } & \multicolumn{1}{|c|}{ Tingkat Hubungan } \\
\hline 1 & $0,00-0,199$ & Sangat lemah \\
\hline 2 & $0,020-0,399$ & Lemah \\
\hline 3 & $0,040-0,599$ & Cukup \\
\hline 4 & $0,060-0,799$ & Kuat \\
\hline 5 & $0,080-0,100$ & Sangat Kuat \\
\hline
\end{tabular}

Sumber : Siregar, S., Metode Penelitian Kuantitatif

\section{Uji Regresi Linier Sederhana}

Regresi sederhana ini menyatakan hubungan kausalitas antara dua variabel dan memperkirakan nilai variabel terikat berdasarkan nilai variabel bebas. Persamaan yang dipergunakan untuk memprediksi nilai variabel Y disebut dengan persamaan regresi. (Sanusi 2013, 131) Bentuk persamaan dari regresi dinyatakan dengan persamaan matematika, yaitu:

di mana:

$$
\mathrm{Y}=\mathrm{a}+\mathrm{bX}
$$

$\mathrm{Y} \quad$ : nilai prediksi dari variabel $\mathrm{Y}$ berdasarkan nilai variabel $\mathrm{X}$

a : titik potong $\mathrm{Y}$; merupakan nilai $\mathrm{Y}$ ketika $\mathrm{x}=0$

b : kemiringan atau slope atau perubahan rata-rata dalam y untuk setiap perubahan dari satu unik $X$, baik berupa peningkatan maupun penurunan (Sanusi, 2013, 132).

$\mathrm{X} \quad$ : nilai variabel $\mathrm{X}$ yang dipilih 


\section{Uji Hipotesis}

Dalam pengujian hipotesis $\mathrm{H}_{0}$ diterima atau ditolak dengan cara

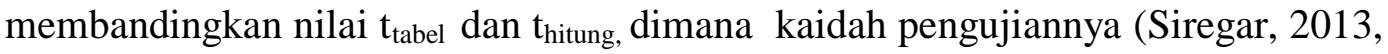
41):

$\mathrm{H}_{\mathrm{o}}$ diterima, jika: $\mathrm{t}$ tabel $<\mathrm{t}$ hitung

$\mathrm{H}_{\mathrm{o}}$ ditolak, jika: $\mathrm{t}_{\text {hitung }}>\mathrm{t}_{\text {tabel }}$

\section{HASIL DAN PEMBAHASAN}

\section{Hasil Uji Validitas data}

Berikut adalah rangkuman dari hasil uji validitas data instrument variable $\mathrm{X}$ dan Y.

Tabel 2

Hasil Uji Validitas Variable $X$ dan $Y$

\begin{tabular}{|c|c|c|c|c|c|c|}
\hline \multirow{2}{*}{ No } & \multirow{2}{*}{ Pernyataan } & \multicolumn{2}{|c|}{$\begin{array}{c}\text { Sistem Informasi } \\
\text { Akuntansi KKP }\end{array}$} & \multicolumn{2}{l|}{ Pencatatan PNBP } & \multirow{2}{*}{ Hasil } \\
\cline { 3 - 6 } & & r hitung & r tabel & r hitung & r tabel & \\
\hline 1 & SDM I & 0,747 & 0,374 & - & - & Valid \\
\hline 2 & SDM 2 & 0,781 & 0,374 & - & - & Valid \\
\hline 3 & SDM 3 & 0,469 & 0,374 & - & - & Valid \\
\hline 4 & PR 1 & 0,695 & 0,374 & - & - & Valid \\
\hline 5 & PR 2 & 0,642 & 0,374 & - & - & Valid \\
\hline 6 & D 1 & 0,693 & 0,374 & - & - & Valid \\
\hline 7 & D 2 & 0,638 & 0,374 & - & - & Valid \\
\hline 8 & SW1 & 0,550 & 0,374 & - & - & Valid \\
\hline 9 & SW 2 & 0,523 & 0,374 & - & - & Valid \\
\hline 10 & SW 3 & 0,442 & 0,374 & - & - & Valid \\
\hline 11 & ITI 1 & 0,507 & 0,374 & - & - & Valid \\
\hline 12 & ITI 2 & 0,541 & 0,374 & - & - & Valid \\
\hline 13 & PNBP1 & - & - & 0,752 & 0,374 & Valid \\
\hline 14 & PNBP2 & - & - & 0,684 & 0,374 & Valid \\
\hline 15 & PNBP3 & - & - & 0,678 & 0,374 & Valid \\
\hline 16 & PNBP4 & - & - & 0,848 & 0,374 & Valid \\
\hline 17 & PNBP5 & - & - & 0,778 & 0,374 & Valid \\
\hline
\end{tabular}

Sumber: data olahan SPSS

Dari hasil analisis didapat nilai skor item dengan skor total. Nilai ini kemudian kita bandingkan dengan nilai $r_{\text {tabel }} . r$ tabel dicari pada signifikan $5 \%$ dengan cara jumlah sampel dikurangi 2. Jumlah sampel pada penelitian ini adalah 30, jadi 30-2 didapatlah $\mathrm{r}_{\text {tabel}}$, sehingga dapat disimpulkan bahwa hasil uji validitas data $\mathrm{r}_{\text {hitung }}$ lebih besar dari $r$ tabel yaitu 0,374 (lihat lampiran tabel $r$ dimana jumlah sampel dikurangi 2/n-2) jadi sesuai dengan ketentuan jika $r$ hitung besar dari $r$ tabel maka instrument penelitian dapat dikatakan valid.

\section{Hasil Uji Reliabilitas}

Berikut merupakan hasil uji reliabilitas variabel penelitian. 
Tabel 3

Hasil Uji Reliabilitas Variabel

\begin{tabular}{|r|r|}
\hline $\begin{array}{c}\text { Cronbach's } \\
\text { Alpha }\end{array}$ & N of Items \\
\hline .861 & 17 \\
\hline
\end{tabular}

Sumber: output SPSS

Dalam penelitian ini, untuk menguji reliabilitas peneliti mengukur tingkat reliabilitas instrumen dengan nilai alpha cronbach's, dimana jika nilai alpha cronbach's > dari 0,6 maka instrumen penelitian dikatakan reliable, namun jika nilai alpha cronbach's < 0,6 maka instrumen penelitian tidak reliabel. Dari hasil uji reliabilitas didapat bahwa alpha cronbach's yang dihasilkan oleh intrsumen penelitian adalah 0,861 berati 0,861 >0,6, sehingga instrumen penelitian bisa dikatakan reliabel.

\section{Hasil Uji Korelasi}

Berikut merupakan hasil dari uji korelasi dari penelitian ini:

Tabel 4

\section{Hasil Uji Korelasi Penelitian}

\begin{tabular}{|c|c|c|c|}
\hline & & $\begin{array}{c}\text { SISTEM INFORMASI } \\
\text { AKUNTANSI KKP }\end{array}$ & $\begin{array}{l}\text { PENCATATAN } \\
\text { PNBP }\end{array}$ \\
\hline \multirow[t]{2}{*}{$\begin{array}{l}\text { SISTEM INFORMASI } \\
\text { AKUNTANSI KKP }\end{array}$} & $\begin{array}{l}\text { Pearson Correlation } \\
\text { Sig. (2-tailed) }\end{array}$ & 1 & $\begin{array}{r}.503 \\
.005\end{array}$ \\
\hline & $\mathrm{N}$ & 30 & 30 \\
\hline \multirow[t]{2}{*}{ PENCATATAN PNBP } & $\begin{array}{l}\text { Pearson Correlation } \\
\text { Sig. (2-tailed) }\end{array}$ & $\begin{array}{l}.503 \\
.005\end{array}$ & 1 \\
\hline & $\mathrm{N}$ & 30 & 30 \\
\hline
\end{tabular}

**. Correlation is significant at the 0.01 level (2-tailed).

Sumber: outpus SPSS

Korelasi SIA KKP dan Pencatatan PNBP menunjukkan angka 0,503. Dimana jika nilai korelasi (r) 0,40-0,59 maka tingkat hubungan adalah cukup. Jadi dari hasil uji korelasi menunjukkan bahwa korelasi antara kedua variabel memiliki hubungan yang Cukup. Melihat tingkat signifikasi antara Sistem Informasi Akuntansi (Komputerisasi Kegiatan Pertanahan) dan Pencatatan Penerimaan Negara Bukan Pajak (PNBP) pada tabel corelations sebesar 0,005, dimana 0,005 $<0,01$ yang berarti terdapat korelasi yang signifikan antara kedua variabel.

\section{Hasil Uji Regersi Liner Sederhana}

Berikut merupakan hasil dari uji regresi liner sederhana.

\section{Tabel 5}

\section{Hasil Uji Regresi Liner}

\begin{tabular}{|c|c|c|c|c|}
\hline Model & $\mathrm{R}$ & $\mathrm{R}$ Square & Adjusted R Square & $\begin{array}{c}\text { Std. Error of the } \\
\text { Estimate }\end{array}$ \\
\hline 1 &, $503^{\mathrm{a}}$ &, 253 &, 227 & 1,714 \\
\hline
\end{tabular}

a. Predictors: (Constant), SISTEM INFORMASI AKUNTANSI KKP Sumber: output SPSS 
Dilihat dari hasil pengolahan data dapat disimpulkan bahwa nilai $\mathrm{R}$ Square dalam tabel adalah sebesar 0,253, angka $\mathrm{R}$ Square disebut juga koefisien determinasi. Angka tersebut menunjukkan bahwa pengaruh Sistem Informasi Akuntansi (Komputerisasi Kegiatan Pertanahan) terhadap Pencatatan Penerimaan Negara Bukan Pajak (PNBP) adalah sebesar 25,3\%, sedangkan sisanya sebesar 74,7 \% dipengaruhi oleh faktor lain. Besarnya nilai R square berkisar antara 0-1, artinya semakin kecil R Square maka semakin kecil pula hubungan antara dua variabel, namun jika sebaliknya $\mathrm{R}$ Square mendekati 1 maka hubungan kedua variabel semakin kuat.

\section{Hasil Hipotesis}

Uji Koefisien Regresi Sederhana (Uji t)

Uji ini digunakan untuk mengetahui apakah variabel independen (X) berpengaruh secara signifikan terhadap variabel dependen (Y). Signifikan berarti pengaruh yang terjadi dapat berlaku untuk populasi (dapat digeneralisasikan).

$\mathrm{H}_{\mathrm{o}} \quad$ : Sistem Informasi Akuntansi (Komputerisasi Kegiatan Pertanahan) tidak berpengaruh terhadap pencatatan Penerimaan Negara Bukan Pajak (PNBP) Pada Kantor Pertanahan Kabupaten Bengkalis.

$\mathrm{H}_{\mathrm{a}}$ : Sistem Informasi Akuntansi (Komputerisasi Kegiatan Pertanahan) berpengaruh terhadap Pencatatan Penerimaan Negara Bukan Pajak (PNBP) Pada Kantor Pertanahan Kabupaten Bengkalis.

Tabel 6

Coefficients

\begin{tabular}{|c|c|c|c|c|c|c|}
\hline \multirow{2}{*}{\multicolumn{2}{|c|}{ Model }} & \multicolumn{2}{|c|}{ Unstandardized Coefficients } & \multirow{2}{*}{$\begin{array}{c}\text { Standardized } \\
\text { Coefficients } \\
\text { Beta }\end{array}$} & \multirow[b]{2}{*}{$\mathrm{t}$} & \multirow[b]{2}{*}{ Sig. } \\
\hline & & $\mathrm{B}$ & Std. Error & & & \\
\hline & (Constant) & 10,397 & 3,723 & & 2,793 & ,009 \\
\hline & $\begin{array}{l}\text { SISTEM INFORMASI } \\
\text { AKUNTANSI KKP }\end{array}$ & ,246 & 080 &, 503 & 3,083 & ,005 \\
\hline
\end{tabular}

a. Dependent Variable: PENCATATAN PNBP

Sumber : SPSS 2018

Dari tabel coefficients dapat dianalisis sebagai berikut:

a. Koefisien regresi variable Sistem Informasi Akuntansi (Komputerisasi Kegiatan Pertanahan) (X) sebesar 0,246 berarti setiap peningkatan penggunaan Sistem Informasi Akuntansi (Komputerisasi Kegiatan Pertanahan) sebesar 1 maka memiliki pengaruh terhadap Pencatatan Penerimaan Negara Bukan Pajak (PNBP) sebesar 0,246 atau dapat dikatakan setiap peningkatan penggunaan Sistem Informasi Akuntansi (Komputerisasi Kegiatan Pertanahan) $100 \%$ maka memiki pengaruh terhadap Pencatatan Penerimaan Negara Bukan Pajak (PNBP) sebesar 24,6 $\%$. Koefisien yang didapat bernilai positif menandakan bahwa terjadi hubungan positif antara penggunaan Sistem Informasi Akuntansi (Komputerisasi Kegiatan Pertanahan) terhadap Pencatatan Penerimaan Negara Bukan Pajak (PNBP).

b. Dari hasil analisis data diatas dapat diketahui nilai t hitung sebesar 3,083 dengan tingkat signifikansi 5\% atau 0,05 . Dari table distribusi t dicari 
pada a : 5\%: $2: 2.5 \%$ (uji 2 sisi) dengan derajat kebebasan (df) n-k-1 atau $28-2-1=25$. Dengan pengujian 2 sisi (signifikansi $=0,025$ ) hasil diperleh untuk $\mathrm{t}$ tabel adalah 2.060 . Kriteria pengujian adalah: Jika $\mathrm{t}$ table $<\mathrm{t}$ hitung maka Ho diterima, tetapi jika t hitung > t tabel maka Ho ditolak. Dari hasil yang diperoleh didapatkan bahwa nilai $t$ hitung $>t$ table (3.083 $>$ 2.060) maka Ho ditolak. Hal ini dapat dikatakan bahwa ada pengaruh secara signifikan antara penggunaan Sistem Informasi Akuntansi (Komputerisasi Kegiatan Pertanahan) dengan kenaikan kualitas Pencatatan Penerimaan Negara Bukan Pajak (PNBP).

\section{Gambar 1}

Besar nilai $\mathrm{r}$ variabel $\mathrm{x}$ terhadap $\mathrm{y}$

\begin{tabular}{|c|c|c|}
\hline $\begin{array}{c}\text { Sistem Informasi } \\
\text { Akuntansi KKP } \\
\text { Variabel (X) }\end{array}$ & $r=25,3 \%$ & $\begin{array}{c}\text { Pencatatan PNBP } \\
\text { Variabel (Y) }\end{array}$ \\
\hline
\end{tabular}

Sumber: hasil analisis data

\section{Sistem Informasi Akuntansi (Komputerisasi Kegiatan Pertanahan) Dan Pencatatan Penerimaan Negara Bukan Pajak (PNBP) Menurut Pandangan Islam}

Kantor Pertanahan Kabupaten Bengkalis meskipun merupakan instansi Pemerintah yang tidak ada unsur aturan syariah didalamnya tetapi sistem yang diterapkan sangat sesuai dengan prinsip syariah islam yakni sesuai dengan perintah Allah SWT dalam surat Al-Baqarah ayat 282. Kantor Pertanahan Kabupaten Bengkalis melakukan pencatatan secara tepat dan akurat dengan menggunakan dua sistem yaitu Sistem Informasi Akuntansi (Komputerisasi Kegiatan Pertanahan) dan Pencatatan Manual entry. Dalam melakukan transaksi kepada pemohon Kantor Pertanahan Kabupaten Bengkalis memberikan Surat Bukti Setor (SBS) yang telah diterbitkan oleh Sistem Informasi Akuntansi (Komputerisasi Kegiatan Pertanahan) yang telah ditanda tangani oleh Petugas Penerima Setoran PNBP sebagai bukti tertulis atas transaksi yang dilakukan kepada pemohon, hal ini bertujuan untuk menjaga keadilan dan kebenaran pemohon dalam melakukan transaksi pada Kantor Pertanahan Kabupaten Bengkalis.

Kemudian agar lebih tepat dan akurat lagi Surat Bukti Setor (SBS) yang telah tercetak oleh Sistem Informasi Akuntansi (Komputerisasi Kegiatan Pertanahan) dibukukan lagi nilai transaksinya sesuai dengan jenis dan tarifnya oleh Petugas Penerima Setoran PNBP, jadi Sistem Informasi Akuntansi (Komputerisasi Kegiatan Pertanahan) dan Pencatatan Penerimaan Negara Bukan Pajak (PNBP) Menurut PP No. 128 Tahun 2015 pada Kantor Pertanahan Kabupaten Bengkalis sudah sesuai dengan padangan Islam.

\section{KESIMPULAN}

1. Berdasarkan hasil penelitian yang dilakukan bahwa Sistem Informasi Akuntansi (Komputerisasi Kegiatan Pertanahan) yang diterapkan pada Kantor Pertanahan Kabupaten Bengkalis telah diterapkan sejak tahun 2010 yang berawal dari dekstop dan pada tahun 2012 diperbaharui menjadi aplikasi yang 
berbasis web. Sistem Informasi Akuntansi (Komputerisasi Kegiatan Pertanahan) diharapkan sangat membantu Kantor Pertanahan Kabupaten Bengkalis dalam menjalankan tugas dan fungsinya, namun terdapat hambatan yang dialami oleh Sistem Informasi Akuntansi (Komputerisasi Kegiatan Pertanahan) seperti seringnya mengalami gangguan jaringan sehingga menghambat pelayanan dan mempengaruhi hasil Pencatatan Penerimaan Negara Bukan Pajak (PNBP). Berdasarkan hasil penelitian yang dilakukan meskipun telah menerapkan Sistem Informasi Akuntansi (Komputerisasi Kegiatan Pertanahan), Pencatatan Penerimaan Negara Bukan Pajak (PNBP) secara manual entry harus dilakukan sesuai dengan surat edaran dari Kementerian Agraria Dan Tata Ruang/Badan Pertanahan Nasional No. 2874/2.2-100/VI/2016 tanggal 22 juni 2016 perihal Revisi Buku Pedoman Penatausahaan, Pembukuan dan Pertanggungjawaban Bendahara yang mengatur tentang tata cara dan pedoman Pencatatan Penerimaan Negara Bukan Pajak (PNBP). Sistem Pencatatan Penerimaan Negara Bukan Pajak (PNBP) pada Kantor Pertanahan Kabupaten Bengkalis telah sesuai dengan Peraturan Pemerintah Nomor 71 Tahun 2010 yang dimana pencatatan dilakukan secara akrual basis. Petugas Penerima Setoran PNBP juga harus melakukan rekon internal dengan admin KKP dan memberikan penjelasan selisih angka dalam Berita Acara Rekonsiliasi Internal jika terjadi selisih sesuai dengan surat edaran Kementerian Agraria dan Tata Ruang/Badan Pertanahan Nasional Kantor Wilayah Badan Pertanahan Nasional Provinsi Riau dengan nomor surat 3382/3-14.100/XI/2017 tanggal 28 November 2017 perihal membuat buku penerimaan/Pembantu penerimaan yakni menindaklanjuti surat Inspektur Kementerian Agraria dan Tata Ruang/Badan Pertanahan Nasional nomor 35/44-900/XI/2017 tanggal 1 November 2017 tentang penyampaian laporan hasil pemeriksaan kinerja dilingkungan Kantor Wilayah Badan Pertanahan Nasional Provinsi Riau yang memerintahkan bendahara penerimaan/pembantu penerimaan PNBP

2. Berdasarkan hasil Analisis data yang dilakukan terdapat pengaruh positif sebesar 25,3 \% dari penerapan Sistem Informasi Akuntansi (Komputerisasi Kegiatan Pertanahan) pada kantor Pertanahan Kabupaten Bengkalis terhadap Pencatatan Penerimaan Negara Bukan Pajak (PNBP). Sisa nya 74,7 \% dipengaruhi oleh faktor-faktor lain. Dan dari analisis data didapat bahwa nilai $t_{\text {hitung }}$ lebih besar dari $t_{\text {tabel }}$ yakni 3.083>2.060 sehingga $\mathrm{H}_{\mathrm{o}}$ ditolak dan $\mathrm{H}_{\mathrm{a}}$ diterima.

3. Berdasarkan hasil penelitian yang dilakukan Sistem Informasi Akuntansi (Komputerisasi Kegiatan Pertanahan) dan Pencatatan Penerimaan Negara Bukan Pajak (PNBP) pada Kantor Pertanahan Kabupaten Bengkalis sudah sesuai dengan padangan Islam yaitu seperti yang Allah SWT perintahkan dalam surat Al-Baqarah ayat 282.

\section{DAFTAR PUSTAKA}

Adnan, M. Akhyar. 2005. Akuntansi Syariah: Arah, Prospek \& Tantangannya. Yogyakarta: UII Press. 
Aviana, Putu Mega Sevya. 2012. "Penerapan Pengendalian Internal Dalam Sistem Informasi Akuntansi Berbasis Komputer". Jurnal Ilmiah Mahasiswa Akuntansi, Vol.1. No.4 Juli 2012, hal: 65-70.

Arikunto, Suharsimi. 2010. Prosedur Penelitian Suatu Pendekatan Praktik. Jakarta: PT Rineka Cipta

Arsip Kantor Pertanahan Kabupaten Bengkalis.

Azwar, Saifuddin. 2011. Metode Penelitian. Yogyakarta: Pustaka Pelajar.

Baridwan, Zaki. 2011. Sistem Informasi Akuntansi. Yogyakarta: BPFE.

Bastian, Indra. 2007. Sistem Akuntansi Sektor Publik. Jakarta: Salemba Empat

Daud, Nanang A. 2016. Ayat dan Hadist Akuntansi. (Web: https://syariahekonomi45.blogspot.co.id/2016/04/ayat-dan-hadist-akutansisyariah.html). Tanggal Akses 05/02/2018.

Departemen Agama Republik Indonesia. 2005. Al-hikmah Al Quran dan Terjemahannya. Bandung: Diponegoro.

Efendi, David, dkk. 2013. "Pengaruh Sistem Informasi Akuntansi Dan Kinerja Karyawan terhadap Keefektifan Pengendalian Internal Di Koperindo Jatim Cabang Nganjuk". Jurnal Cahaya Aktiva, Vol. 03 No. 2, hal:71-80, September 2013.

Gustani. 2017. Ayat Al-Quran landasan Akuntansi Syariah. (Web: http://akuntansikeuangan.com/ayat-al-quran-landasan-akuntansi-syariah/). Tanggal Akses: 05 Februari 2018.

Harahap, Sofyan Syafri. 2001. Akuntansi Islam. Jakarta: PT. Bumi Aksara.

Hariwijaya, M. 2008. Cara Mudah Menyusun Proposal Skripsi Tesis \& Disertasi. Yogyakarta: Pararaton Publishing.

Helmawati. 2015. Sistem Informasi Manajemen. Bandung: PT Remaja Rosdakarya.

Hery. 2011. Teori Akuntansi. Jakarta, Prenada: Media Group

Indralesmana, Kadek Wahyu dan Suaryana, I.G.N. Agung. 2014. "Pengaruh Penerapan Sistem Informasi Akuntansi terhadap Kinerja Individu Pada Usaha Kecil dan Menengah Di Nusa Penida". E-jurnal Akuntansi Universitas Udayana, Vol.8 No.1., hal:14-26, ISSN: 2302-8556.

Jusup, Al Haryono. 2011. Dasar-dasar Akuntansi. Yogyakarta: Sekolah Tinggi Ilmu Ekonomi YKPN.

Krismiaji. 2010. Sistem Informasi Akuntansi. Yogyakarta: UPP STIM YKPN.

Lamonisi, Sony. 2016. "Analisis Penerapan Standar Akuntansi Berbasis Akrual Pada Pemerintah Kota Tomohon”. Jurnal EMBA, Vol.4 No.1 Maret 2016, hal: 223-230.

Massweeto. 2018. Pengertian Pencatatan dan pelaporan. (Web: https://www.scribd.com/doc/311955908/Pengertian-Pencatatan-Dan-

Pelaporan). Tanggal Akses: 02 Februari 2018.

Mc.Leod, Raymond dan Schell, George. 2004. Sistem Informasi Manajemen. Jakarta: PT. Indeks.

PP No. 128 Tahun 2015 tentang Jenis dan Tarif Penerima Negara Bukan Pajak yang Berlaku pada Kementerian Agraria dan Tata Ruang/ Badan Pertanahan Nasional.

Priadana, Moh. Sidik dan Muis, Saludin. 2009. Metologi Penelitian Ekonomi \& Bisnis. Yogyakarta: Graha Ilmu. 
Raharjo, Sahid. 2014. Uji Regresi Sederhana dengan SPSS Lengkap. (Web: https://www.konsistensi.com/2014/06/uji-regresi-sederhana-denganspss.html). Tanggal Akses 07 Februari 2018.

Rama, Dasaratha V., dan Jones, Frederick L. 2008. Sistem Informasi Akuntansi. Jakarta: Salemba Empat.

Riahi, Ahmed dan Belkaoui. 2006. Accounting Theory. Jakarta: Salemba Empat.

Romney, Marshall B dan Steinhart, Paul John. 2006. Sistem Informasi Akuntansi. Jakarta Selatan: Salemba Empat.

Sanusi, Anwar. 2011. Metodologi Penelitian Bisnis. Jakarta Selatan: Salemba Empat.

Sekaran, Uma. 2006. Research Methods For Business. Jakarta: Salemba Empat.

Silviana dan Antoni, Erwin. 2014. "Pengaruh Sistem Informasi Akuntansi Terhadap Kualitas Laporan Keuangan Pemerintah Daerah Survey pada Pemerintah Daerah di Seluruh Jawa Barat". Jurnal Profita, Vol.6 No.1 April 2014, hal: 24-36.

Siregar, Syofian. 2013. Metode Penelitian Kuantitatif. Jakarta: Prenada Media Group

Subramanyam, K. R. dan Wild, John J. 2010. Ananlisis Laporan Keuangan. Jakarta: Salemba Empat.

Sugiyono. 2014. Metode Penelitian Manajemen. Bandung: Alfabeta.

Sujarweni, V.Wiratna. 2015. Akuntansi sektor Publik. Yogyakarta: Pustaka Baru Press.

Suwadjono. 2009. Akuntansi Pengantar. Yogyakarta: BPFE Yogyakarta

Syafrudin. 2014. Pencatatan dan Pelaporan dalam Kesehatan Masyarakat. (Web: http://materi-paksyaf.blogspot.co.id/2014/04/pencatatan-dan-pelaporandalam.html). Tanggal Akses: 03 Februari 2018.

Teguh, Muhammad. 2005. Metode Penelitian Ekonomi Teori dan Aplikasi. Jakarta: PT. Raja Grafindo Persada

UU No. 20 Tahun 1997 Penjelasan dan tentang PNBP.

Yadiati, Winwin dan Wahyudi, Ilham. 2006. Pengantar Akuntansi. Jakarta: Kencana Prenada Media Group.

http://www.bpn.go.id/PUBLIKASI/Inovasi/Komputerisasi-Layanan-Pertanahan http://www.bpn.go.id/Tentang-Kami/Sejarah

http://www.bpn.go.id/TENTANG-KAMI/Sekilas-ATR-BPN 